\title{
江戸における城下町の都市設計*
}

〜町割の湛範と街道・水系の関係〜

A study on the design of urban structures in Edo City

\author{
阿部 貴弘**、篠原 修*** \\ by Takahiro ABE and Osamu SHINOHARA
}

abstract: Edo had well-woven urban structures composing of waterways and streets. These structural complexities have interested researchers for a long time. The purpose of the study is to understand the principles of design in the residential areas of Edo which had not been fully understood. In the study, using modern surveying maps, the sizes of the blocks and the angles of the crossing streets were measured and analyzed, considering the effect of topography. The authors estimated and certified the formation of the urban structure in each residential area, and the method in which the blocks were arranged concerning main streets and waterways.

\section{1 はしめに}

1590（天正18）年、家㻖が仕可してから江户時 代の初期にかけて、江户は大きな変化を遂げた。大

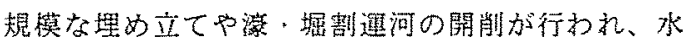
路や街路の入り組んだ非常に䶂雑な、しかし面白い 都市模造を有する都市へと発展していった。こうし た水路網の発達した江きにおいて、都市がどういつ た通程で設計されていったのかを解き明かすこと は、非常に舆昧梁い所であり、都市史・建築史の分 野で長い間研究が行われてきた。

\section{2 江户に関する既存研究}

都市史・建築史の分野にお当既存研究は、その 方法論により、次のように大まかに分類できる。

1.文献を資料として用いた、文献学的アプローチ

2.地節調查結果や発掘資料を用いた、考古学的ア プローチ

3、地図や絵図資料を用いた、都市地理学的アプ 口-チ

本研究は、分析に地困を凟粼として用いている点 で都市地理学的アプローチに位晸づけることができ るが、その中でも特に、都市の微地形的側面をも含 んで分析を行っている点に、方法論的特徴がある。

\footnotetext{
* keywords : 江户、町人地、部市被計、地形・水菜

** 学生会是 東京大学大学院修士 1 年 社会基盤工学整攻

*** 正会員 工掊 東京大学大学院教授 社会基盤工学森攻

( 113 慗京都文京区本鄉7 $-3-1$ )
}

以下に、都市地理学的アプローチで得られている 既存研究を中心に、榃題を簢笚にまとめてみる。

\section{（1）町割の基準}

まず、定説として町割の基準が明らかになってい るい。江戸の街区は、京間60間四方の正方形街区が 基染であり、街区内の盯犀政は、街路に面して間口 を持ち、その奥行きは京間20間であった。街区の四 辺に奥行き20間の屋敖が割り付けられたので、中央 に汒20間四方の、会所地と呼ばれる空地が存在し た。また、一つの町は街路に面した雨側の町家で形 成されていた。このような町の配䍘形式は「雨側 町」と轷壮れており、江㞾限らず近地城下町では 一般的な町のあり方と見てよいが、江戸の場合街区 が正方形で、縦横の通りそれぞれに面して両側町と なっていることが特徵であった。1657（明暦3）年 の明暼の大火以後、会所地を買通する街路（これを 新道と呼ぶ）が通され、会所地の建物化が始まっ to。

町割の基华に関する、より即地的な研究では、ま

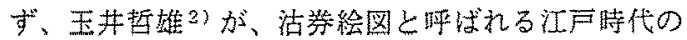
絵困を基に、メインストリートであった日本橋通り と本町通りの関係を解明している。宫本雅明引舛、 本町通り・日本橋通りなどの晒線、江戸図屏風に見

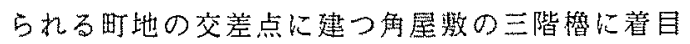
し、ヴィス夕に基づいて都市設計が行われたと結諭 づけている。また、鈴木理生4)は、微地形に着目し て、都市が排水を最偠先に洘え設計されたとしてい る。しかし、これらの研究に扔いては、定説とされ るまでの研究成果は得られておらず、町割と水系. 地帅との閔係は明らかになっていない。 
（2）漫・堀割運河等の水系の設計

鈴木理生引が、地質調查結果、近世考古学の資料 を基に非常に咩細な研究を行い、都市の全体的な 嫁・堀割運河等の水系設部の実際について言及して いる。しかし、地区単位でのより具体的な水系設計 については明らかになっていない。

\section{（3）都市全体の計画・設計}

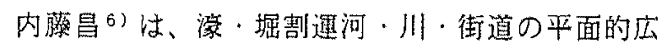
がりや、武家地・町人地・寺社地・見附（城門）の 配醢に着目し、都市が右渦巻状、つまり「の」の字 状に発展していつたとしている。鈴木理生》は、地 質調查結果、近世考古学の資料を基に、マクロな視 点からの都市計画・設計の過程を解明している。都 市の計画・設計に関しては、マクロな視点から大筋 は明らかになっているものの、地区単位での計面、 設計の実際は明らかになっていない。

\section{3 目的・対象}

以上のような既存研究を受けて、本論では、近世 城下町江戸の下町町人地を対象に、

1.町割と、その水系、街道との関係における設計 基梁の存在の有無

2.地区単位での計画・設計の实際 の解明を武みる。

\section{4 分析方法}

\section{(1) 既存研究の分析視点}

既存研究には、街区形䳆・主要街路の軸のとり 方・微地形に着目したものがある。街区形態に着目 した研究8)のでは、街区が基染から「ずれ」ている のかいないのかのみに着目され、基染からのずれの 度合いやずれの要因にはふれられていない。ま要街 路の軸に着目した研究10) 11) 12) 13)でも同様に、軸がず れているのかいないのかのみに着目され、ずれの度 合いやずれの要因にはふれられていない。一方、微 地形に着目した研究(4)15)16)からは、江戸の主要街道 が微高地を通っていたことが明らかになっている。

\section{(2) 本研究の分析視点}

これらの研究成果を踏まえ、本研究では、街区形 態・街路交差角・微地形を定量的に分析することを 武みる。

\section{a) 街区形態}

地図の計測により、街区が、町割の基制とされて いる京間60間四方の正方形街区加ら、どの程度ずれ
ているかに着目する。ずれが小さく、60間四方の正 方形街区に近い街区が多い地区では、基染に則った 町割が行われたといえる。一方、ずれが大きい場合 でも、街区形態や街区湢・街区の角度に統一性がみ られれば、その地区では何らかの基準があり、その 基染に基づいて町割が行われたとみることができ る。ずれが大きく、街区に何の統一性もみられない 不整形街区が多い地区では、町割に対して水系や地 形などの別の何らかの要因が、大きな影響を与えて いると考えられる。

\section{b) 街路交差角}

地図の計測により、街路の交差角が基染からどの

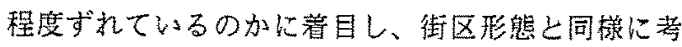
える。街路が直角に交差している地域では、基染に 則った町割が行われたといえる。直交していなくて も、交差角に統一性が見られれば、その地域では何 らかの基染があり、その基準に基づいて町割が行わ れたとみることができる。交差角に何の統一性も見 られない場合、そこでは、水系や地形などの別の何 らかの要因が、町割に対して大きな影響を与えてい ると考えられる。

以上のように街区形態・街路交差角のずれの度合い に着目することで、設計の際何が倀先されたのかを 明らかにすることができると考える。

\section{c) 微地形}

既存研究により、江戸の主要街道は微高地を通つ ていたことが明らかになっている1718119。町人地で は、街道がメインストリートであったことから、都 市設計を㜔み解くに当たつて有效と考元、分析の視 点に加えた。

\section{（3）計測方法}

\section{a) 街区辺の長さの計測}

計測は、明治初期（明治17年〜明治18年）に内務 省地理局によって発行された縮尺 5 千分の1の東京 実测全図 ${ }^{20)}$ (以下、内務省図と呼ぶ）上で行う。さ らに、国立歷史民俗博物館に上り作成された、江戸 時代の復元図 ${ }^{21)}$ の町屋の街区を内務省図に対応させ て計测する。内務省图は、近代测量によって作成さ れた最初の精密な測毁图である。江戸時代の復元図 には、寛永期、寛文・延宝期、草末期、の3 種があ る。これらは、内務省图などを基本图とし、それに 江户時代の各時期の絵図を照合し、おとしたもので ある。町家の中には後の堀の開削等により、計湘で きないものがある。これらの町家は、計測対象外と する。さらに、江户前島地区の京橋〜新掎間は、明 
治時代（明治 5 年〜明治 10 年）に入って街路の拡幅 整備が行われたので、内務省図では江戸時代に比 べ、街区がやや小さくなっていると考えられる。 計測結果は、京間の間を単位として表すが、

1 .計測する地図の縮尺が 5 千分の 1 であること

2 .計測の際の単位はメートルで、計測に用いた三

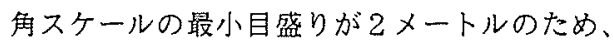
2メートルごとの計測であり、それを間単位に 変換し、さらに小数点以下を四捨五入している こと

から、1間程度は誤差としてあらわれてくると考え られる。

$$
\begin{aligned}
& 1 \text { 間 }(\text { 京間 })=6.500 \text { 尺 }=1.970 \mathrm{~m} \\
& 1 \mathrm{~m}=3.300 \text { 尺 }=0.508 \text { 間 }(\text { 京間 })
\end{aligned}
$$

\section{b ) 角度計測}

計測には内務省図を用い、街路の中心線の交差角 を計測する。

\section{c) 微地形}

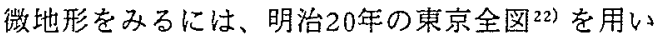
る。この地図は尺を単位とした詳細な等高線表示を した地図で、標高20尺以下は 1 尺ごと、標高 20 尺以 上は 5 尺ごとに等高線が入っており、微地形をみる に適した地図である。

\section{d）内務省図と参謀本部図}

内務省図と同時期（明治 19 年〜明治 20 年）に、参 謀本部陸軍部测量局が作成した、同じく縮尺 5 千分 の1の東京図 ${ }^{23)}$ (参謀本部図) がある。これも近代 测量によって作成された地図である。本研究で、参 謀本部の地図ではなく内務省図を用いたのは、1.参謀 本部の地図では街区と道路の境界が明示されていな いため街区の特定が難しい点、2.原図どうしをつなぎ 合わせる祭、参謀本部の地図のほうが街路・湪・堀 割運河の幅員に誤差が大きい点、3.江戸時代の復元図 が、絵図を内務省図におとして作成されている点、4. 微地形を見る際用いた地図が内務省図系の地図であ る点による。

\section{5 分析結果}

\section{（1）江戸前島地区}

\section{a）日本橋一京橋間（図1）}

ここは、外嫁・日本橋川・京橋川・㮯川に围まれ た地区である。日本橋と京橋を結んで、日本橋通り が通されている。寛永期には、ここには船入堀が あったが、1690（元禄 3）年までに全て埋められた (図5）。
計測の結果からこの地区をみると、以下のように なる。

1 ）街区形的（図2）

1.京橋川、日本燆泔沿いに不整形街区が存在す る。

2.日本橋通りに平行方向の街区幅は、中橋広小路 を挟んでほぼ60間で整合性が保たれている。

3.日本橋通りに垂直方向の街区幅は、街道の雨側 一皮はほぼ60間に保たれているが、その外側、 外嫁側は56〜 58間、相川側は64〜 66間となって いる。

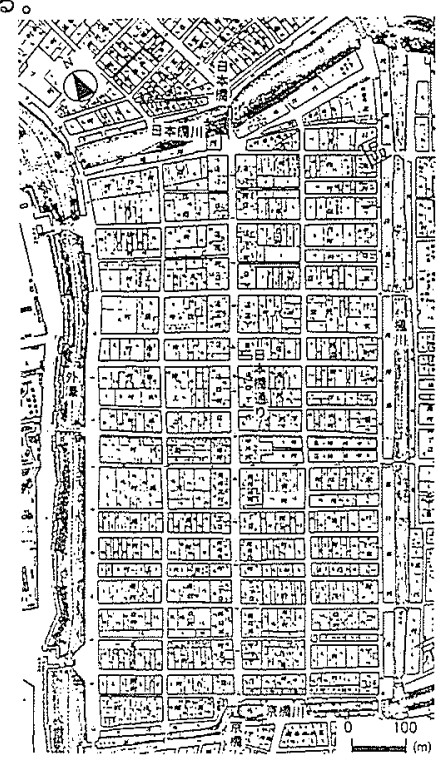

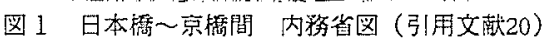

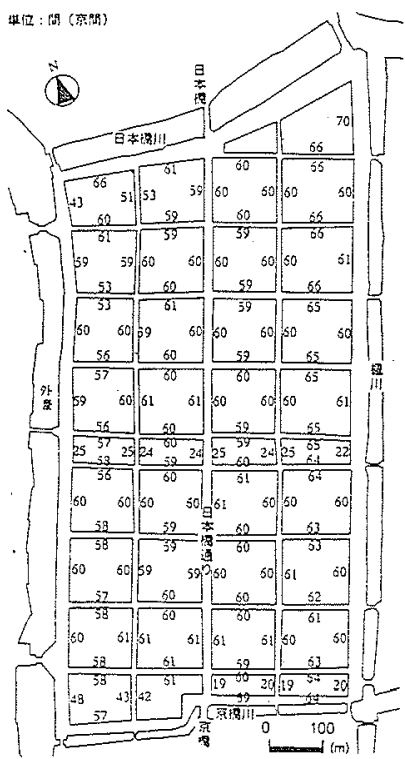

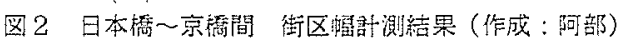




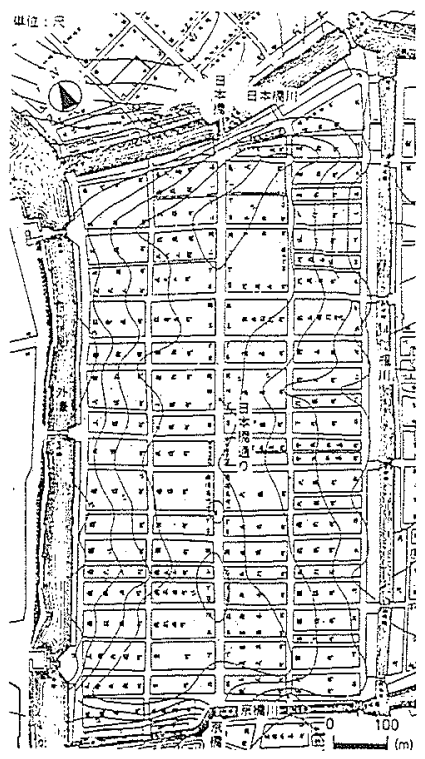

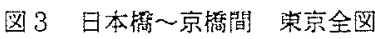
(引用文献22)

2）街路交差角

街路は直角に交差している。

3) 微地形 (図3)

1.微高地に日本橋通りが通されている。 2.低地に沿って京橋川が屈折している。

以上の結果から、次のように分析できる。

1 、㴚・堀割運河際は濛・堀割運河に影留を受けた 町割が行われたと考えられる。

2. 日本橋通りを相川側に $3 \sim 4$ 間程度ずらせば、 日本橋通りと垂直方向に街区幅 60 間ずつの 4 列の 町割が可能だが（図4）、そうしていない。これ は、日本橋通りを微高地に通すことを最優先と し、それを軸に町割が行われたためであるといえ る。従って、外嫁・椢川の開削位置は、町割の基 準とは別の原理で決められたと考えられる。

3. 日本橋通りに平行方向の街区幅が、中橋広小路 （船入堀があったところ(図5））を挟んで60間で 整合しており、また、他の船入、堀があったところ で町割が船入堀の影響を受けていないことから、 船入堀と町割は、同時期に計画・設計されたと考 えられる。

4. 京橋川は、低地に沿って開削したために屈折し ていると考えられる。

5.この地区の屋敷割および新道の方向をみると、

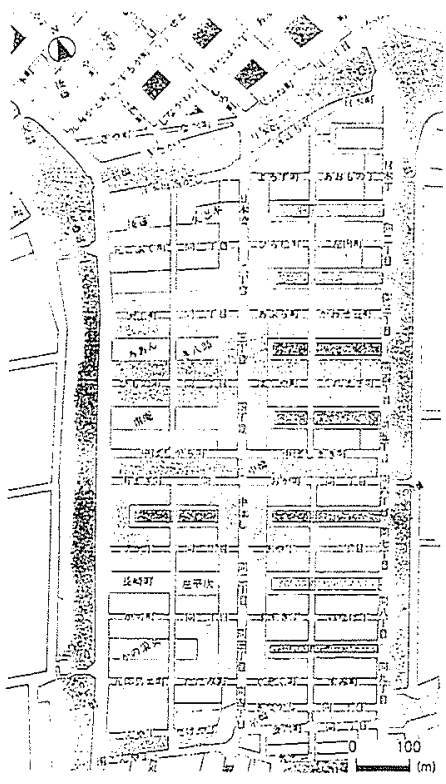

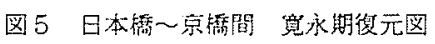
(引用文献21)

(作成：阿部)

街区角地の屋敖割は、日本橋通り沿いは日本橋通 りに表を向けているが、他の場所では日本橋通り に垂直な街路の方に向いている。また、新道も日 本橋通りに対して重直方向に通されている。この ことから、この地区では日本橋通りに垂直方向の 街路設計が卓越していたといえる。これは、通り に垂直に開削されていた船入堀の影㸷もあると考 えられる。

\section{b) 京橋一新橋間（図6）}

ここは、外濠・京橋川・汐留川・三十間堀に囲ま れた地区である。京橋と新橋を結んで、日本橋通り が通されている。明治初期（明治 5 年〜明治 10 年）に 街路の搪張整備が行われたので、計測に用いた内務 省図では街区が小さくなっている。

計測の結果からこの地区をみると、以下のように なる。

\section{1) 街区形態（図7）}

1.嫁・㻕割運河沿いに不整形街区が存在する。

2. 日本橋通りに平行方向の街区幅は、整合性が保 たれている。

3.日本橋通りに垂直方向の街区幅は、ばらつきが 大きくなっている。

4.図7の点線で囲まれた地区では、奥行きほぼ20間 の長方形街区が2街区取られている。 
2）街路交差角

街路は真角に交差している。

3 ) 微地形（図8）

微高地に日本撟通りが通されている。

以上の絬果から、次のように分析できる。

1.濛・堀割運河際は嫁・堀割運河に影得を受けた 町割が行われたと若えられる。

2、日本榙通りを外渃僋にずらせば、通りの両側に 60間の街区を取ることも可能だが（図9）、そうし ていない。これは：日本橋通りを微高地に通すこ とを最儤先とし、それを䡛に町割が行われたため であるといえる。つまり、日本槁〜京撟間と同様

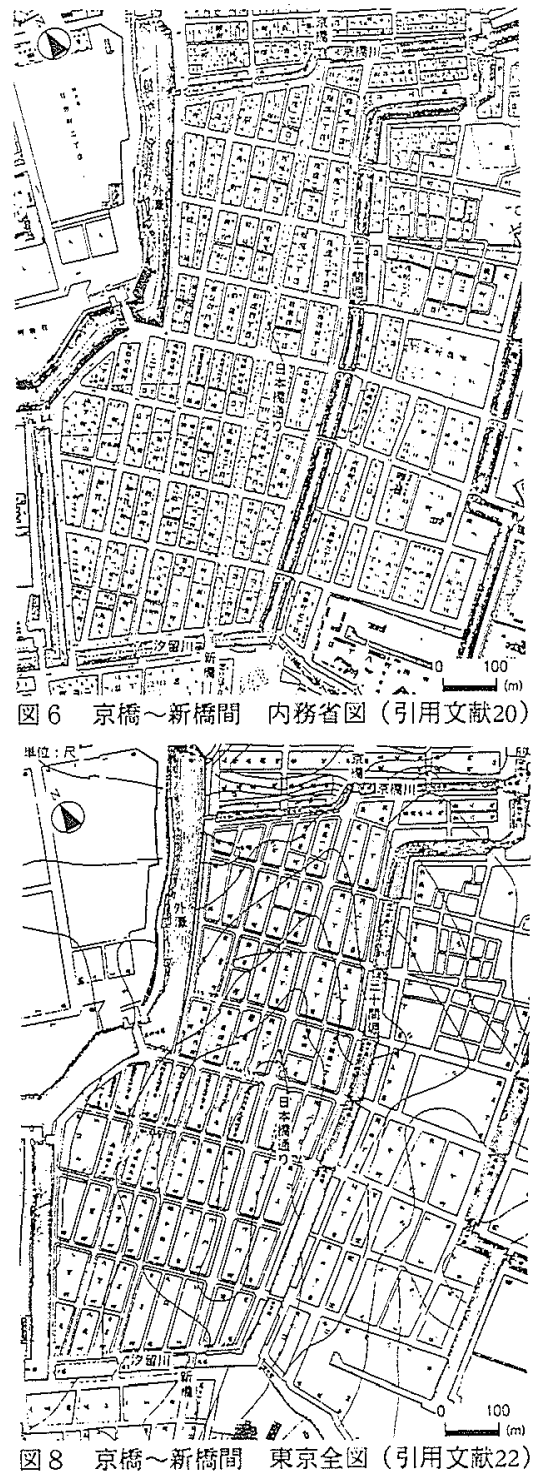

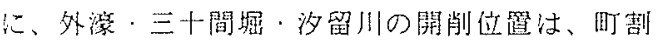
の基準とは別の原理で決められたと考えられる。

3.図7の点線で䧃まれた地区では、京橋川と三十間 堀の間に奥行き20間の街区がとれるように、三十 間堀を屈折させて開削したと考えられる。

4.この地区の屋敖割少よび新道の方向をみると、 街区筩地の屋敖割は、日本橋通りに平行な街路の 方に向いている。また、新道も日本部通りに対し て平行方向に通されている。このことから、この 地区では日本售通りに平行方向の街路設計が卓越 していたといえる。日本橪〜京橋間では、日本简 通りに琶直方向の街路の秩序が卓越していたこと から、この点に閔して泪地区間で秩序の整合性は 保たれていなかったといえる。

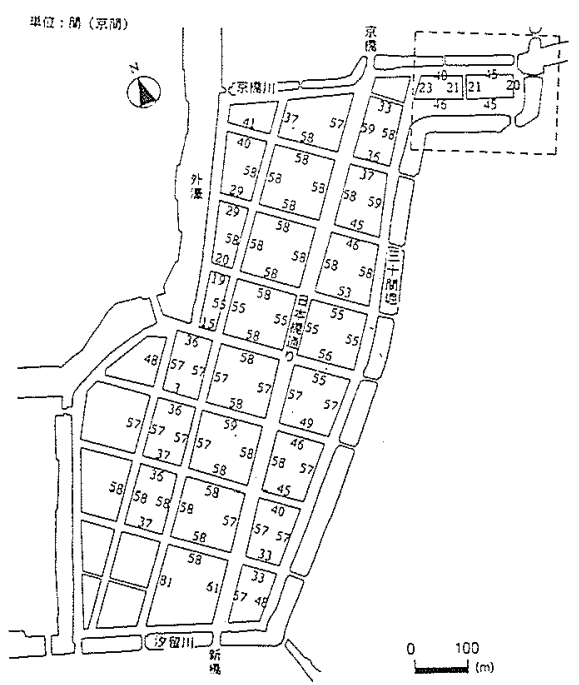

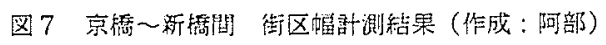

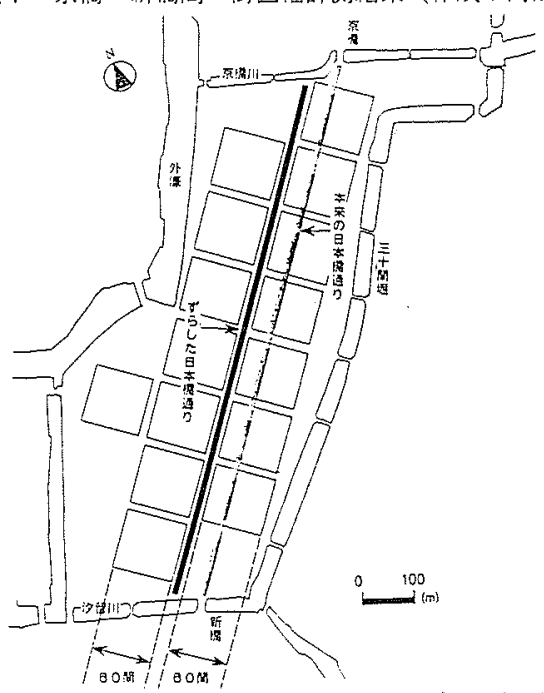

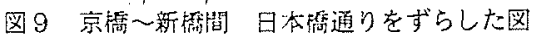
(作成：坷部) 
（2）日本橋北地区（図10）

ここは、外濛・日本撟川と神田川に段まれた地区 である。図10の網かけ部は、寛永期以降堀の開削が 行われたため、当初の街区の計測が出来なかった。 説明の便宜上、この地区を街区形態により $\mathrm{A} \sim \mathrm{G}$ の地 区にブロック分けをする。

計測の結果からこの地区をみると、以下のように なる。

\section{1) 街区形態（図11）}

(1)Aブロック

1.外嫁、日本橋川沿いに不整形街区が存在する。

2.日本橋通りと本町通りが交差するあたりに平行 四辺形街区が存在する。

3.本町通り〜日本橋川間の、日本橋通りに平行方 向の街区湢にばらつきがある。

4. 日本橋通り〜西側日本橋掘留間の、本町通りに 平行方向の街区幅が、通り沿いは60～61間、堀 沿いは64〜65間となっている。

(2) Bブロック

台形街区が存在する。

(3)Cブロック

本町通りに平行方向に長い、長方形街区が多
(4) Dブロック

1.20 間 $\times 60$ 間の街区幅に近い街区が、2 街区 $\times 3$ 街区堀の間に並んでいる。

2.日本橋川沿いに、三角形街区が存在する。

(5)Eブロック

平行四辺形街区と不整形街区が存在する。

(6)Fブロック

60間四方の正方形街区がほとんどである。

(7) G、Hブロック

不整形街区が存在する。

2）街路交差角（図12）

(1) Aブロック

日本橋通り方向の街路と、本町通り方向の街路 が直角から 3 度ずれている（交差角 87 度、93 度）。

(2) B、Cブロック

$\mathrm{A}$ ブロックとBブロックの境で、本町通りは20 度、本石町通りは14度北へ屈折している。これ を受けて、屈折後、Aブロックでは平行だった両 通りが平行ではなくなり、浅草橋へ近づくに 従って間隔が狭くなっていく。また、本石町通 りに対して直交する街路が多い。

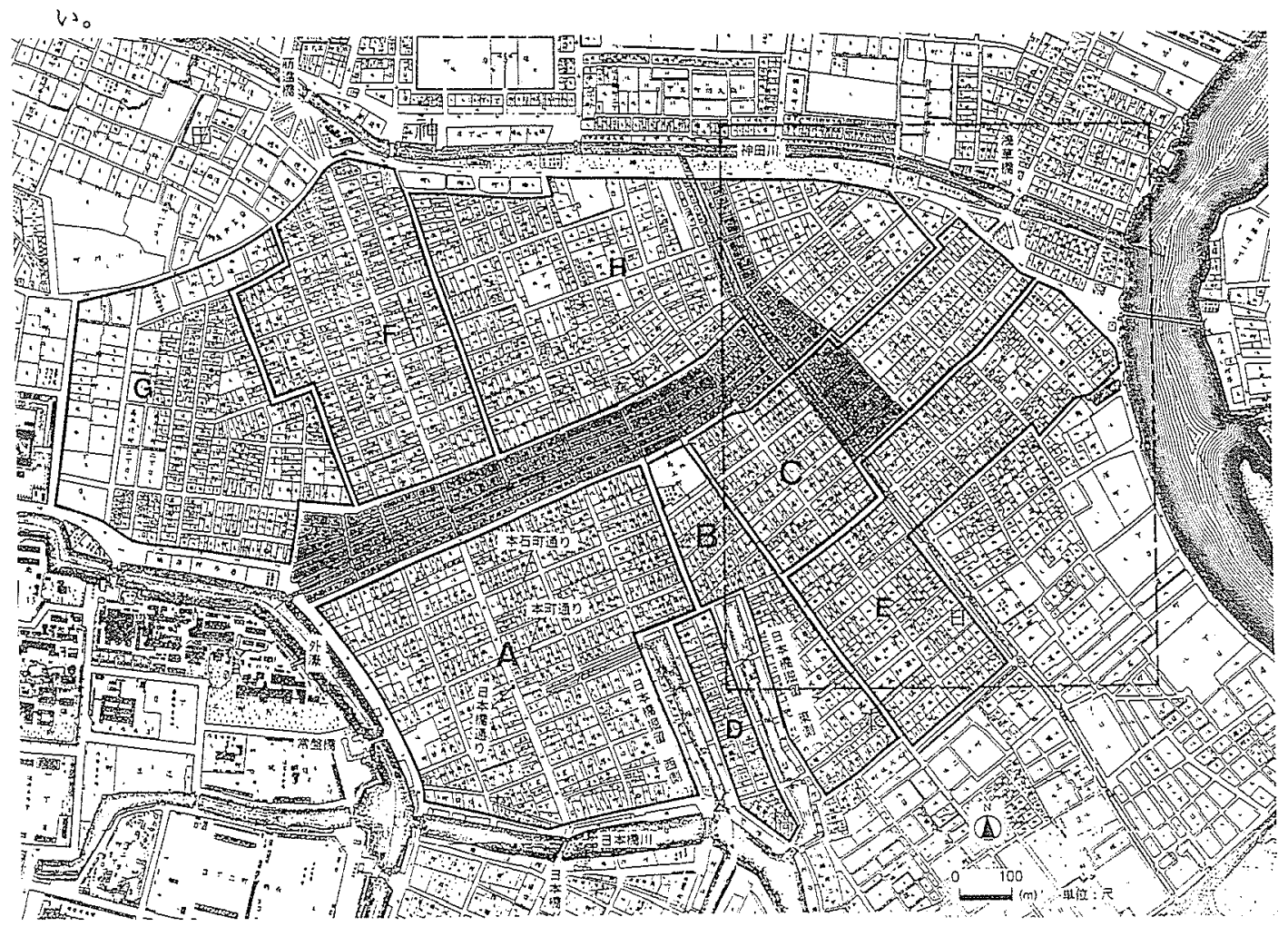

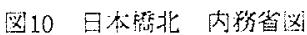

（原图（引用文献20）に抑筑） 


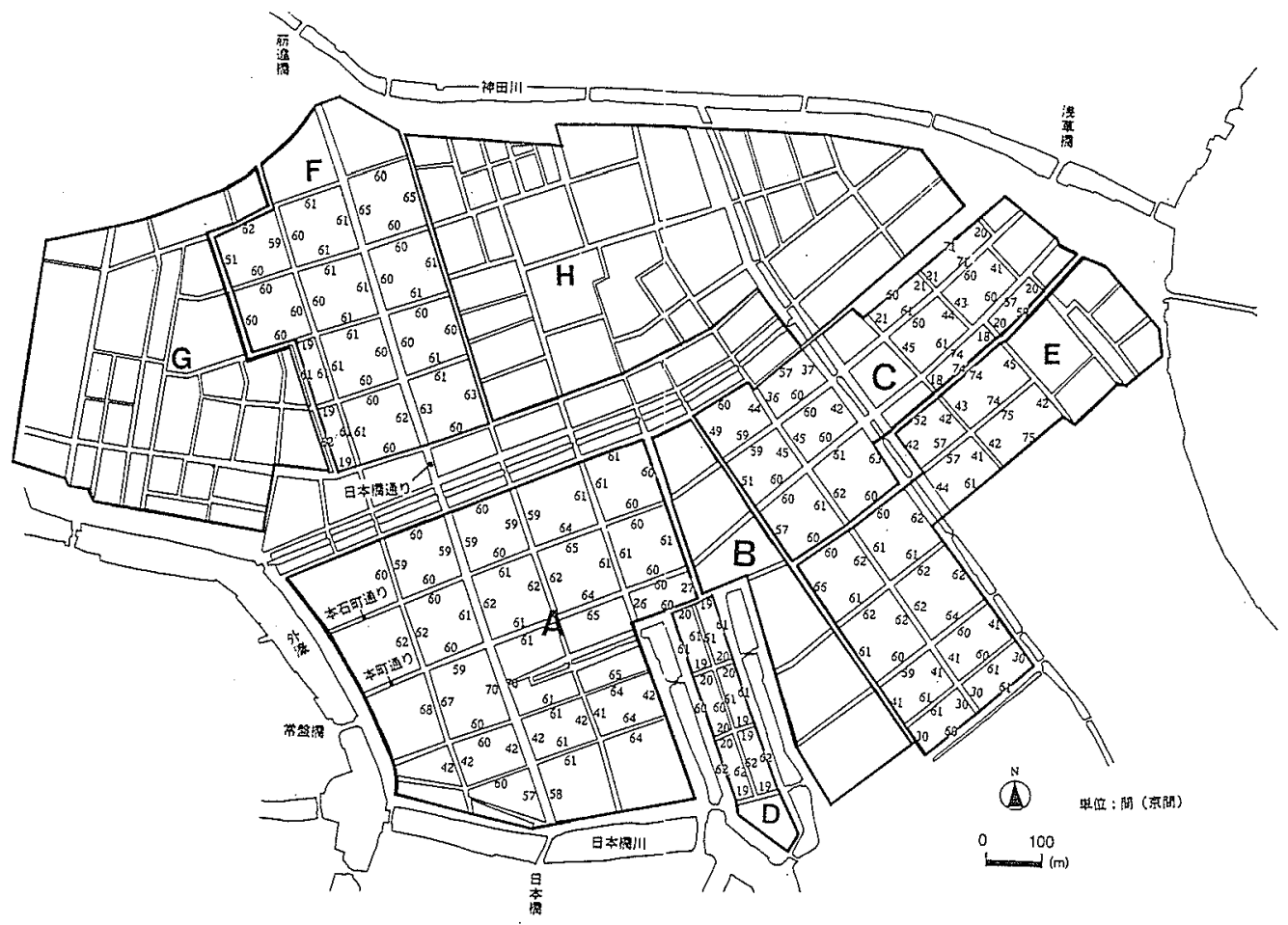

図11 日本撟北 街区幅計測結果（作成：阿部）

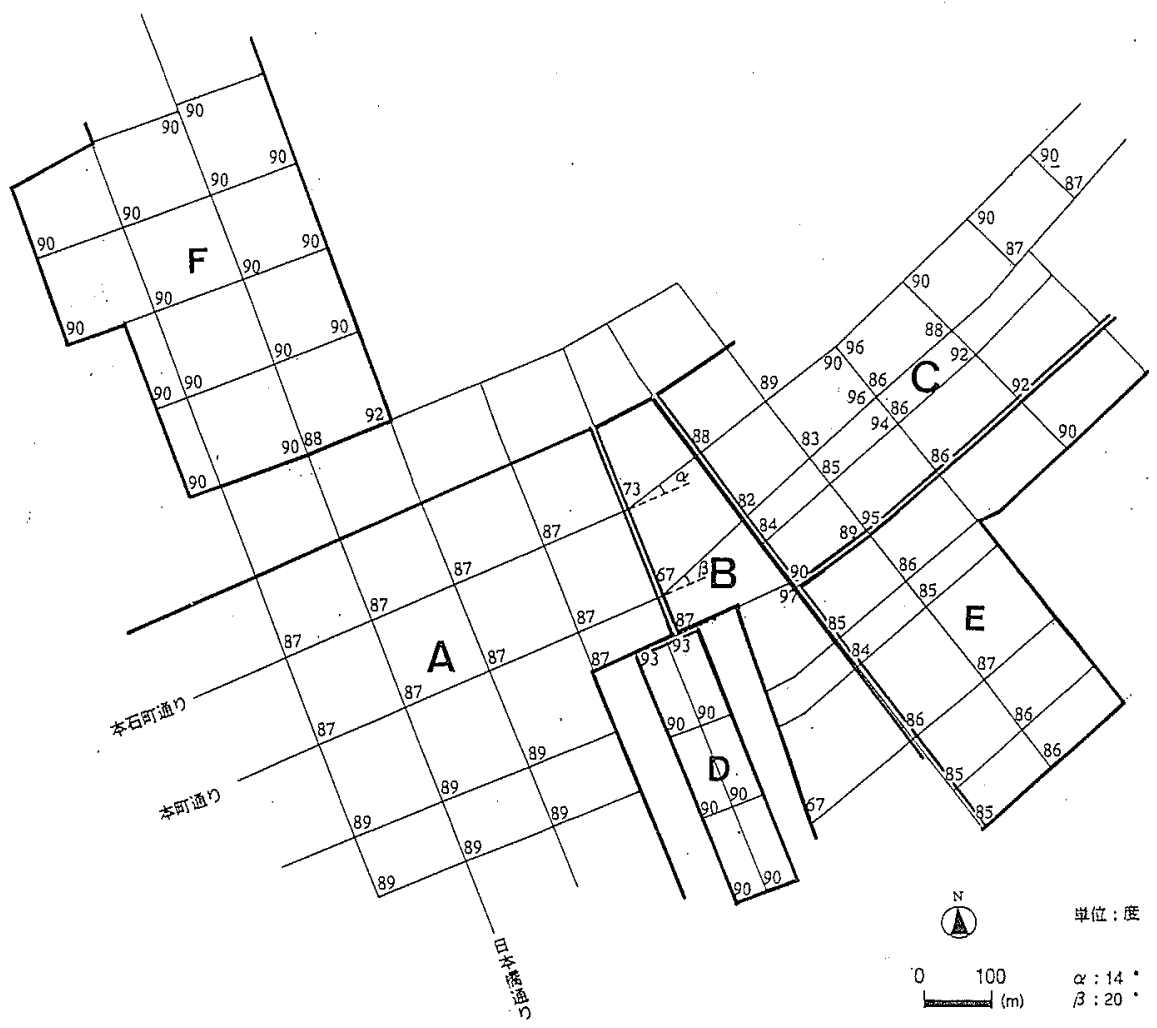

図12 日本繁北 街路交差角計剆結果（作成：阿部） 


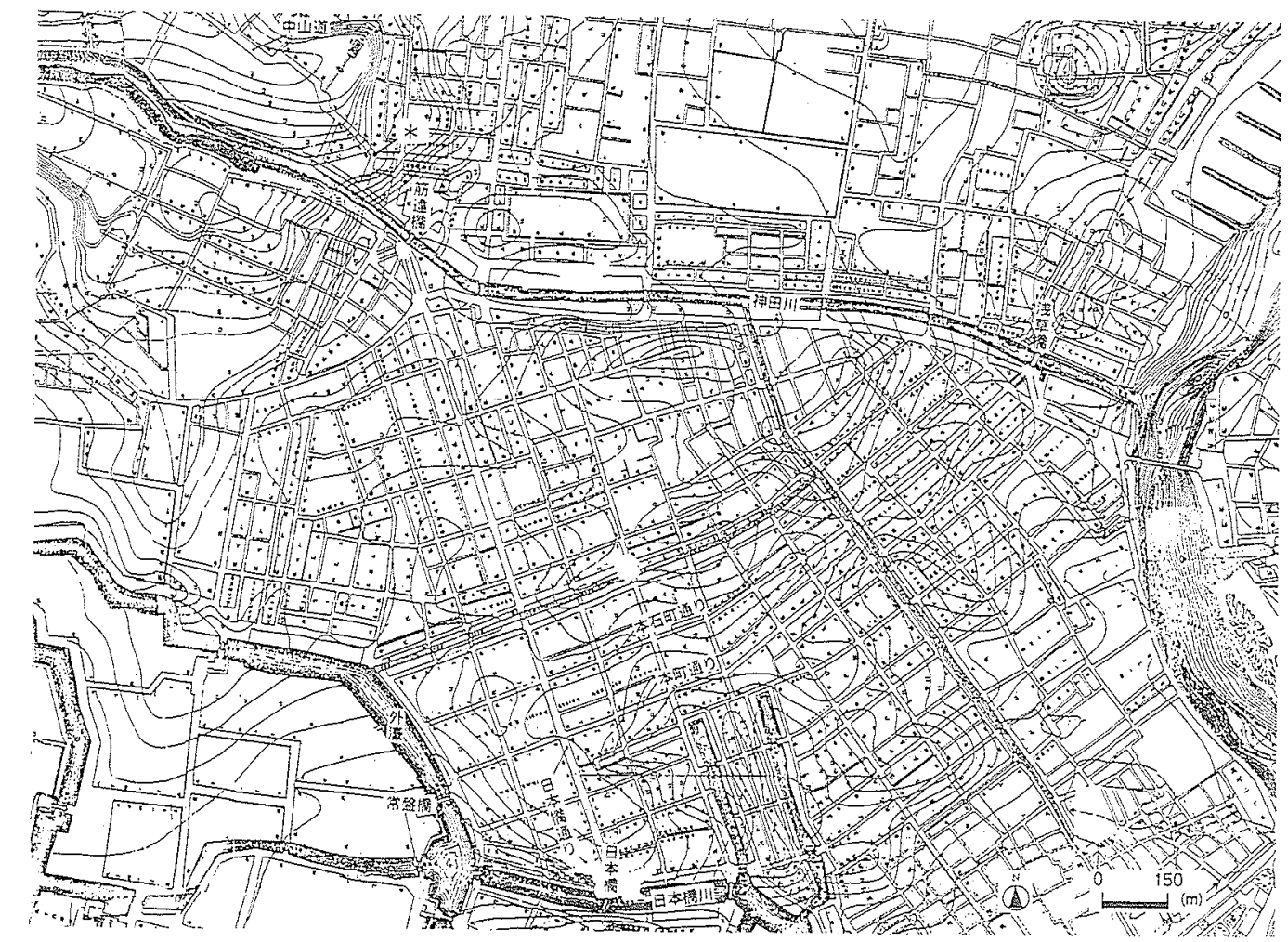

図13日本筬北 柴京全図（引用文献22）

(3) D、Fブロック

街路は直角に交美している。

(4) Eブロック

85度〜87度で交差している街路が多いが、屈曲 している街路もある。

(5) G、Hブロック

屈曲している街路もあり、街路が街区を碁盤目 状に区画するように通されていない。

\section{3) 微地形（図13）}

1.本石町通りが微高地を通つており、微高地に合 わせて屈折している。

2.日本槅掘留の標高が低くなっている。

以上の結果から、次のように分析できる。

1. 本石町通りが微高地を通り、微高地に合わせて 屈折していることから、まず、本石町通りを微高 地に通すことを考えたといえる。

2. B、Cブロックで、本町通りではなく本石町通り に対して直交する街路が多く、また、本石町通り の軸が浅草撟に対してあたっていることから、こ のブロックでは、本石町通りが町割の軸であった と考えられる。
3.Bブロックでは、本石町通りの屈折に合わせて街 路を交差させているために、街区が台形となって いる。

4.Aブロックでは平行である本町通りと本石町通り の間隔が、屈折後狭くなっている。これは、1. 本町通りを浅草橋に近づけようとしたため、2。 本町通りの南にあった堀（図 14）と通りとの間に 町家をとろうとしたため、と洘えられる。この両 通りの幅が狭くなつたために、闌の街区が長方形 となった。

5.Aブロックでは、本町通り・本石町通りに詨して 日本橋通りが直交していないために、街区が平行 四辺形になっている。ここでは、街区の角度を直 角にすることに先立って、通りを通したものと考 えられる。日本橋通りを、本町通り・本石町通り に直交させなかったのは、日本橋北詰と図130筋 違橋の北の*の地点を結ぶように日本栭通りを通 したためと考えられる。*の地点は、尾根筋を 通ってきた中山道がちょうど駿河台を下り切った 地点である。日本橋北詰から、本町通り・本石町 通りに直交するように日本橋通りを通すと（図 15）、日本標通りが中山道に合流するのが毁河台 の中腹になってしまうため、直交させなかったと 


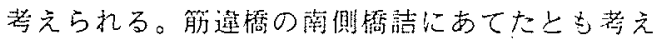
られるが、日本慗通りが通されたときには神田川 が開削されていなかった（1620年に開削）ことか ら、*の地点にあてたと考えるのがより合理的で ある。

6.日本简北詰は、日本橋の架撟位囬によって決ま る。この日本挢の架撟位琶は、次のように决めら れたと思われる。まず、江戸前鼻地区の日本售通 りを微高地に通すことにより、南詰めが決まる。 そこから、江戸前島地区の日本留通りの䧿に合わ

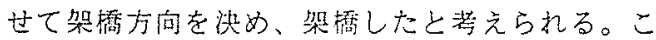
の䧿よりも柬へ振ると橋のスパンが長くなってし まい、西へ振ると、日本撟通りと本町通り・本石 町通りとの交差角がより鋭角になってしまう。

7.Aブロックの外堀・日本橋川沿いは濛・堀割運河 に影響を受けた町割が行われたと荐えられる。

8.Aブロックの本盯通り〜日本橋川間で、日本橋通 りに平行方向の街区幅にばらつきがあるのは、屈 折した西側の日本橋掘留の影響であると考えられ る。

9.Aブロックの日本橋通り〜西側日本橋掘留間で、 本町通りに平行方向の街区湢が不整合なのは、ま ず日本橋通りの東に60間の街区が取れるように街 路を通し、次に堀沿いに街路を通したためである といえる。

10. Dブロックは旧石神井川の旧河口24)であるが、 この地区を見ると、20間 $\times 60$ 間の街区幅に近い街 区が東西方向に2 街区、南北方向に3 街区立び、 整合性が保たれている。微地形を見ると、街区の あるところが微高地となっており、ここが旧河口

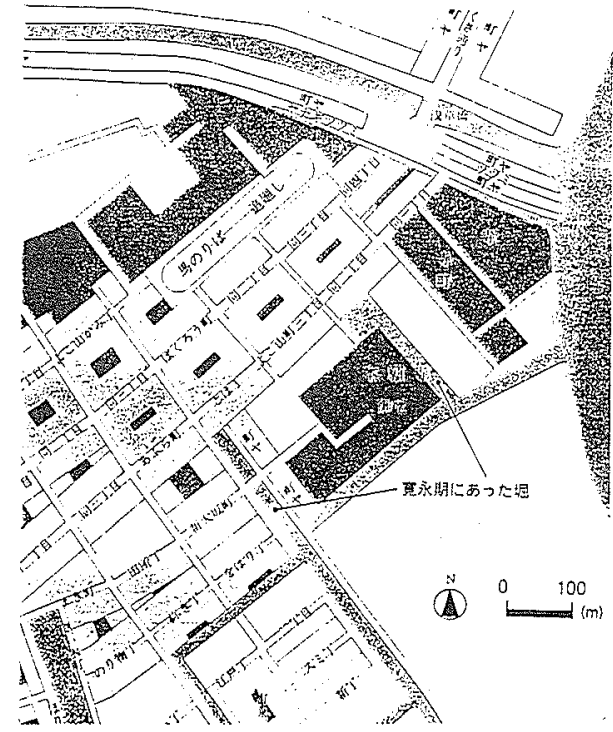

図14 日本橋北 図10点線部寞永朝復元図 （引用文献21）
であったことを考えると、堀の開削の際の土を堀 の聞に盛土した形跡がうかがえる。このことから 洘えて、二本の堀は、堀の間に20間 $\times 60$ 間の街区 幅の街区が、2 街区 $\times 3$ 街区取れるように掘られ たと考えられる。また、西側の堀は、日本衙を扶 んだ日本槜通りの屈折に合わせて㮯川〜西側の堀 が屈折するように、日本挢通りに平行に层ったと 考えることもできる。

11. Fブロックは、日本攜通りを軸に60間四方の街区 をとるよう町割が行われたといえる。

12. Eブロックは、窅永期にあった堀（図14）が後に 埋め立てられて町家となつた地区である。長方形 街区が多いが、街路が屈曲しているため不整形な 街区となっているところもあり、規則性や町割の 軸といったものの存在がみられない。また、地形 的にも特徵がみられない。そのため、この地区に おける基準は見つけられない。

13.G、Hブロックは、不整形街区がほとんどでここ でも基染は見つけられない。街区が碁盤目状とな るように、町割が行われたとは洘えにくい。

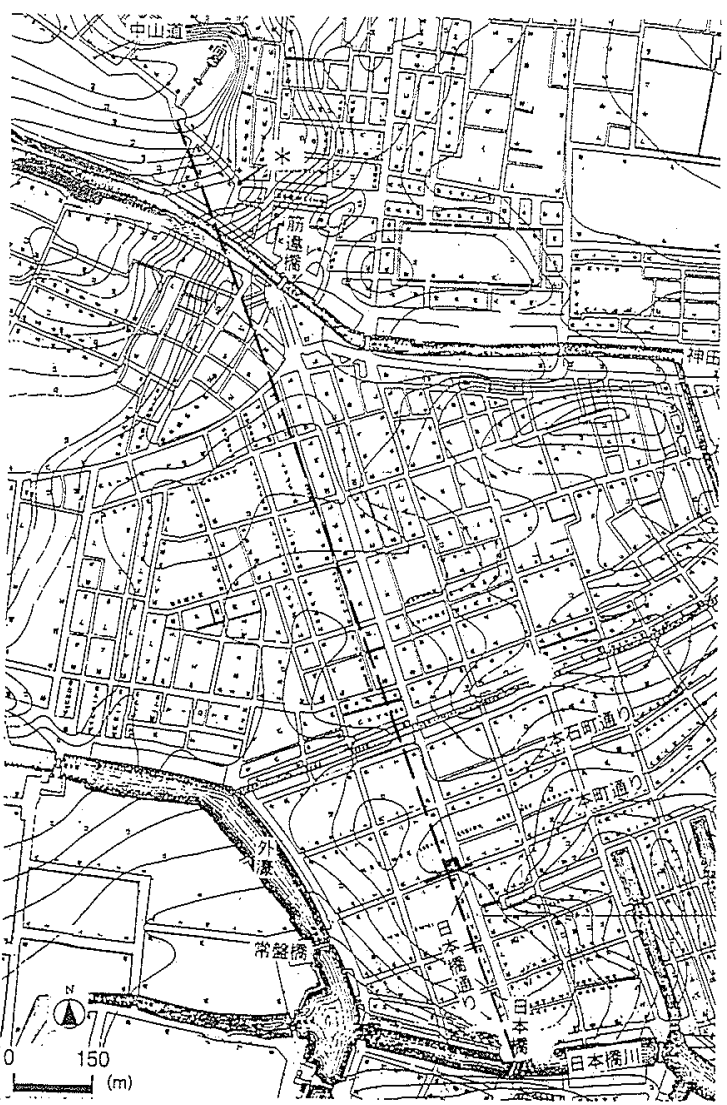

図15 日本橋北 日本简通りをずらした図 （原図（引用文墄22）に加滗） 
（3）漫・堀割運河沿い（図16、17）

濠・堀割運河沿いには、奥行き20間の長方形街区 が多い。これらの街区はみな、倳・堀割運河に面し て配置され、さらに㴚・堀割運河の両側に配監され ていることが多い。江戸時代は舟運が交通の主要な 役割を担っていたことから考えて、背後に町家が発 達していなくても、濛・堀割運河沿いには奥行きほ ぼ20間の町家が配置され、これらの町家が舟運基地 としての役割を担っていたのではないかと考えられ る。

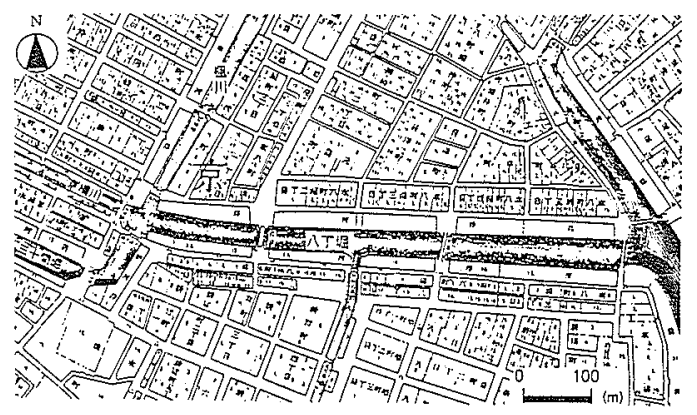

図16 八丁堀船入 内陊省図（引用文苚20）

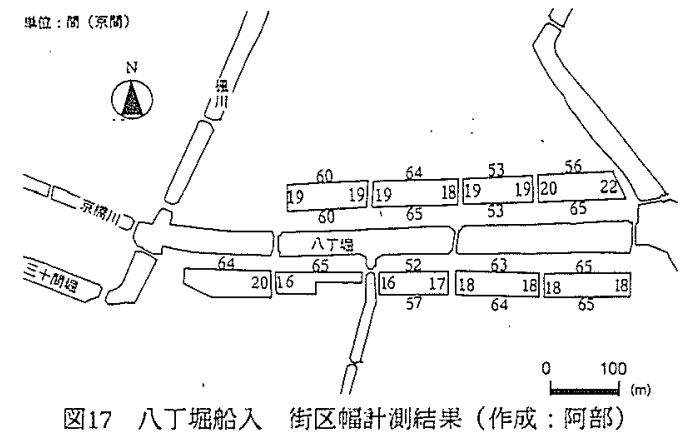

（4）分析結果のまとめ

a）地区単位で明らかになった点

今回の分析により、次の点を明らかにすることが できた。

1．江戸前島地区全体では、まず、日本橋通りが微 高地に通さた。次に、日本橋通りを軸として町割 が行われ、その後、嫁・堀割運河際では嫁・堀割 運河に影響を受けて町割が行われた。ただし、図7 の点線で囲まれた地区では嫁・堀割運河が町割の 影響を受けて開削された。

2、江戸前島地区の日本撟〜京橋間では、町割と船 入堀が同時期に計画された。

3. 日本橋北地区において、既存研究25) 26)では本町 通りが微高地に通されたとしている。しかし、今 回の分析により、微高地に通されたのは本石町通 りであることが分かった。本石町通りがまず微高
地に通され、日本橋通りと本石町通りが交差する 辺りでは、日本橋通りと本石町通りの $2 つ の$ 街路 を軸として町割が行われた。ここを離れると、そ れぞれ日本橋通り・本石町通りのみを軸とする町 割が行われ、最後に嫁・堀割運河際の町割が行わ れた。

4、日本橋掘留周辺では、堀の影響を受けた町割が 行われたが、堀自体も堀の延長や堀間の幅など、 町割の影響を受けて開削された。

5.八丁堀船入などの嫁・堀割運河沿いでは、奥行 きほぼ20間の町屋が、舟運基地として配監され た。

b）地区単位で議諞の余地がある点 次の点については、今回の分析でおおよそ明らか にすることができたが、今後、詳諭の余地があると 考えられる。

1. 本町通り・本石町通りに対して日本橋通りが直 交していないのは、既存研究27では日本橋通りが 旧石神井川の河道に並行に通されたためとしてい る。しかし本研究では、日本橋通りを、日本撟北 詰と図13の筋違橋の北の*の地点、すなわち中山 道が駿河台を下り切る地点を結ぶように通したた め両通りが直交していないと考察した。

2. 日本橋北地区の日本橋通りや本町通り・本石町 通りから離れた地区では、街区を碁盤目状に区画 するように設計していなかったのではないか。こ うした地区はかつては寺社地であったり、古くか ら町が存在していたことから、碁盤目状でない何 か別の基準があったと考光られる。今回の分析で は、こうした地区の町割に関する基準は見つけら れなかった。

3. 日本橋北地区において、本町通り本石町通りが 屈折後両通りの間隔を狭めているが、これは本町 通りが屈折後、浅草橋へのアクセス、本町通りの 南にあった堀（図14）との関保から、本石町通り に近づくよう通されたためであると考えられる。 この両通りの間隔が狭くなったために、間の街区 が長方形となった。

c) 町人地全体

町人地全体では、次のようにまとめることができ る。

1。まず町割の軸となる通りを微高地に通し、次 に、主要な通りを、朝となる通りとの関倸や、地 形・水系などを考虑しながら通す。

2。こ机らの通り沿いの町割を、通りを軸として行 い、玟後に嗱、堀割運河沿いや通りから離れた地 区での町割を行う。 


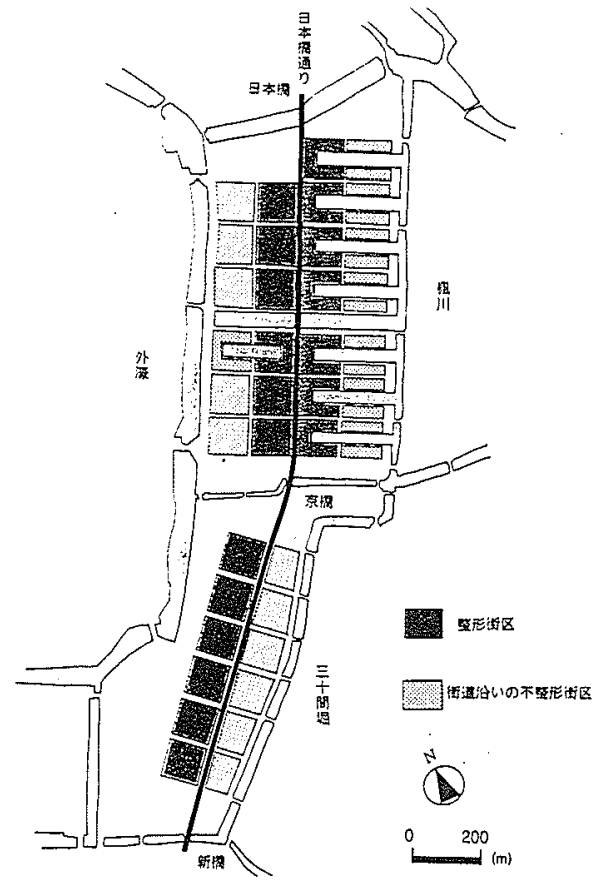

図18 江戸前島地区設計過程-1（作成：阿部）

3.嫁・堀割運河際では㴚・堀割運河の影響を受け た町割が行われたが、一部の嫁・堀割運河では 濛・堀割運河自身が町割の影響を受けて開削され た。つまり、水系と町割の基準では、敩密な整合 性は取られていなかった。

\section{6 計画・設計の実際のまとめ}

分析結果をふまえ、どのような順序で町人地が設 計されていったかを、地区毎にまとめてみる。外 嫁·日本橋川・㮯川・京橋川・三十間堀は、一部を 除き町割に先立って開削されたと考えられるが、街 道位䈯は同時に設定されていたと考えられる。開削 位置は、中世までの江戸の地形に、大きな影響を受 けて決められたと考えられるが、前述したように、 町割との整合性を考虑して泳・堀割運河が開削され た地区もある。神田川は、町割の行われた後、1620 年になって開削された。

\section{（1）江戸前島地区}

1. 微高地に日本橋通りを通し、日本橋通り沿い に、通りを軸とした町割を行う。ただし、日 本㗚〜京橋間では、船入堀との整合性を保っ て町割を行う（図18）。

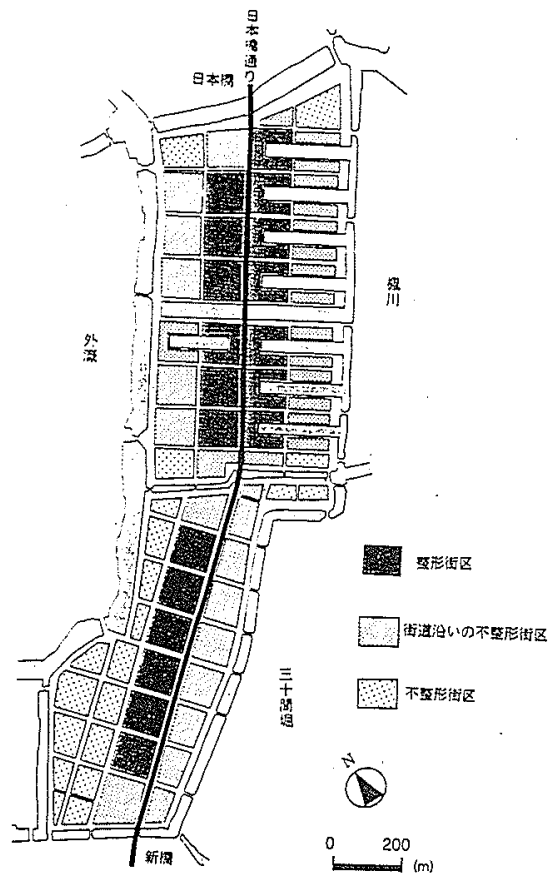

图19 江戸前岛地区設計過程-2（作成：阿部）

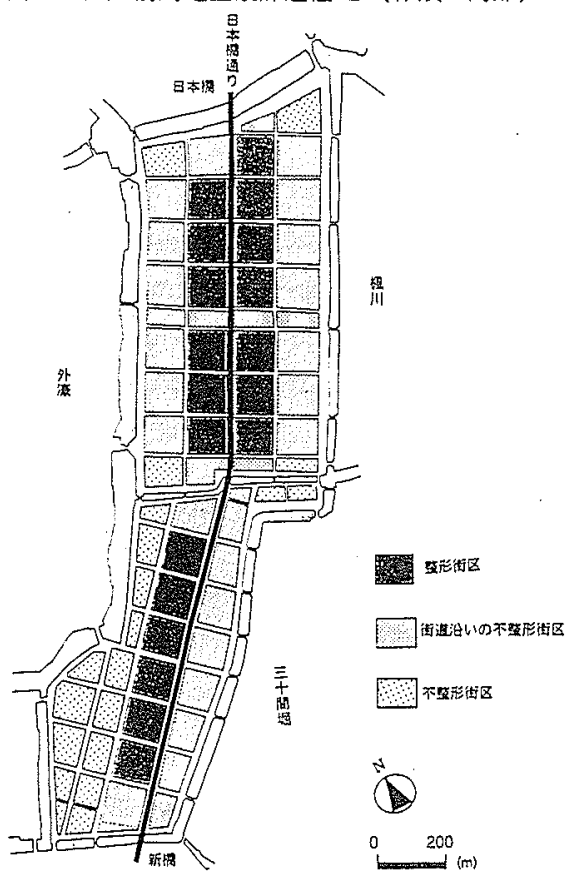

図20，江戸前舄地区設部透程-3（作成：阿部）

2. 嫁・堀割運河際を濠・堀割運河に合わせて町 割を行う（図19）。

3．船入堀を埋め立てて町家とする（図20）。 


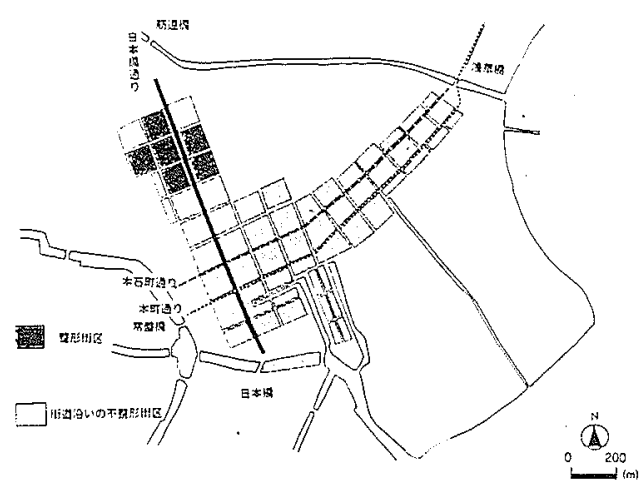

図21日本揣北地区設計過程-1（作成：阿部）

（2）日本橋北地区

l.まず、本石町通りを微高地に通し、その南に 本町通りを通す。日本橋通りを、日本橋北詰 と中山道が毁河台を下りきる地点を結ぶよう に通す。

2.二本の日本橋堀留を、堀の間に取る街区と、

日本橋通りを意識しながら掘る。

3. 日本撟通りと本町通り・本石町通り沿い、お よび日本橋堀留沿いの町割を行う（図21）。

4.嫁・堀割運河際と通りから雄れた地区の町割 を行う（図22）。

\section{7 結論}

1 、城下町の計画・設計を読み解くための視点と して、地図計測に基づく街区形態・街路交差 角・微地形の分析が有効であることがわかっ た。

2、次にその分析の視点に立ち、従来はマクロな 視点のみからしか、明らかにされていなかった 江戸下町町人地の都市の計画・設計の実際を、 地区単位で読み解くことができた。

3、地形、街道と町割との関係を明らかにした。

4.水系と町割の関係を、定量的には明らかにす ることはできなかった。

\section{8 今後の課題}

1、活券図、町触、下水路網（『賽保活券図』） 等の援用により、街路の幅員、洹・堀割運河・ 河岸地の幅員に関する分析も行う必要がある。

2. 㴚・堀割運河の位置・開削年代に関しても研 究の余地がある。

3、江戸の他の地区に関しても、同様の分析を行 う必要があると考えられる。

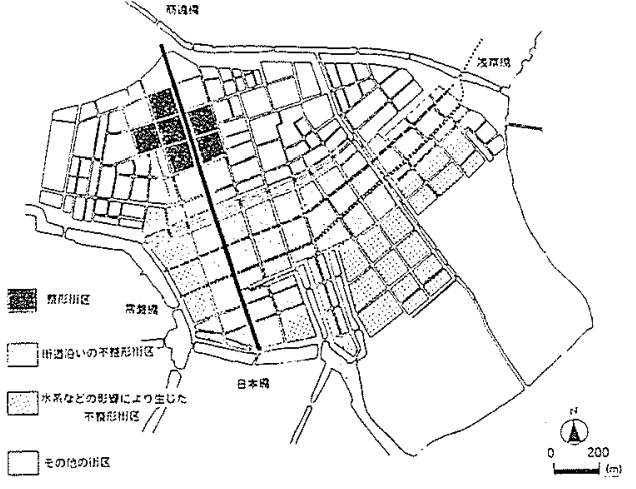

図22日本揣北池区設尌過程-2（作成：阿部） 謝辞

最後に本研究をまとめるにあたり、東京大学建築 学科の伊藤毅先生、千葉大学建築学科の玉井哲雄先 生、都市史研究家の鈴木理生氏から、ご教示を睗つ たことを厚く御礼申し上げます。

引用文嗼

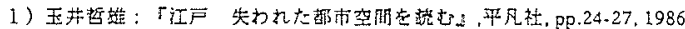

2）引用文献 1), pp.26-27, pp.41-44

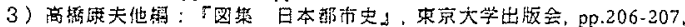
1993年

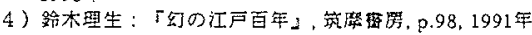

5）引用文献 4 ），po.96-132, pp.183-186, pp.199-205

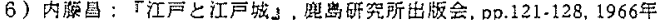

7) 引用文献 4), pp.130-136

8）引用文朝 1), p. 44

9）引用文献 4 )

10）引用文部 1 ), pp.42.44

11）引用文献 3)，pp.206-207

12) 引用文嗝 4)

13）引用文袮 6)，pp121-125

14）引用文觔 1 ) , p p. 39.44

15）引用文㱱 4 )，p.98，pp.132-136

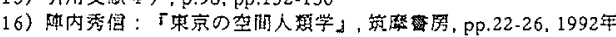

17）引用文就 1)，pp.39-44

18）引用文献 4)，pp.134-136

19）引用文献16）, p p.25-26

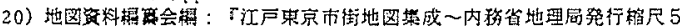

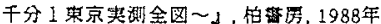

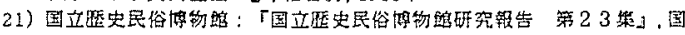
立堅史民绤梅物塆，1989年

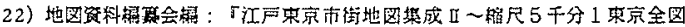
$\sim 1$, 柏整房, 1990年

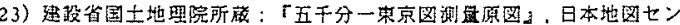
夕一, 1984年

24) 引用文献 4), p.101, p.135

25）引用文献 L)， pp. 39.44

26）引用安献 4)，pp.132-134

27) 引用文献 4 ) ,, 0.135

参洘文献

1)制木理生：「江戸の都市計面」，三省堂, 1988年

2）鈴木理生：「江戸の川染京の川井上落院,1989年

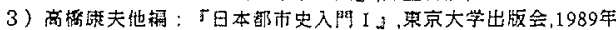

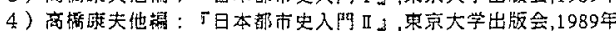

5) 矢守一彦：「城下町のかた去小，筑磨落原，1988年

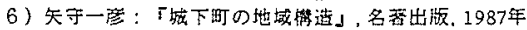

7) 矢守一应：「都市ブランの所究」，大明虽。1970年

8）都市史矿究会桶：「年報都市史研究2 城下町の颣型小，山川出版社， 1994年

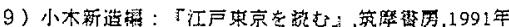

